\title{
The parables of Jesus as critique on food security systems for vulnerable households in urban townships
}

\begin{tabular}{|c|c|}
\hline \multicolumn{2}{|c|}{$\begin{array}{l}\text { Authors: } \\
\text { Ernest Van Eck }{ }^{1}\end{array}$} \\
\hline \multicolumn{2}{|c|}{$\begin{array}{l}\text { Affiliations: } \\
{ }^{1} \text { Department of New } \\
\text { Testament Studies, Faculty of } \\
\text { Theology, University of } \\
\text { Pretoria, South Africa }\end{array}$} \\
\hline \multicolumn{2}{|c|}{$\begin{array}{l}\text { Project Leader: E. van Eck } \\
\text { Project Number: } 2400030\end{array}$} \\
\hline \multicolumn{2}{|c|}{$\begin{array}{l}\text { Description: } \\
\text { This research is part of the } \\
\text { project, 'Socio-Cultural } \\
\text { Readings', directed by Prof. } \\
\text { Dr Ernest van Eck, } \\
\text { Department of New } \\
\text { Testament Studies, Faculty } \\
\text { of Theology, University of } \\
\text { Pretoria. }\end{array}$} \\
\hline \multicolumn{2}{|c|}{$\begin{array}{l}\text { Corresponding author: } \\
\text { Ernest Van Eck, } \\
\text { ernest.vaneck@up.ac.za }\end{array}$} \\
\hline \multicolumn{2}{|c|}{$\begin{array}{l}\text { Received: } 12 \text { Nov. } 2015 \\
\text { Accepted: } 10 \text { May } 2016 \\
\text { Published: } 23 \text { Aug. } 2016\end{array}$} \\
\hline \multicolumn{2}{|c|}{$\begin{array}{l}\text { How to cite this article: } \\
\text { Van Eck, E. \& Mashinini, } \\
\text { M.M., 2016, 'The parables } \\
\text { of Jesus as critique on } \\
\text { food security systems } \\
\text { for vulnerable } \\
\text { households in urban } \\
\text { townships', HTS Teologiese } \\
\text { Studies/Theological Studies } \\
72(3), \text { a3252. http://dx.doi. } \\
\text { org/10.4102/hts.v72i3.3252 }\end{array}$} \\
\hline \multicolumn{2}{|c|}{$\begin{array}{l}\text { Copyright: } \\
\text { (c) 2016. The Authors. } \\
\text { Licensee: AOSIS. This wo } \\
\text { is licensed under the } \\
\text { Creative Commons } \\
\text { Attribution License. }\end{array}$} \\
\hline \multicolumn{2}{|l|}{ Read online: } \\
\hline 口的品: & $\begin{array}{l}\text { Scan this QR } \\
\text { code with your } \\
\text { smart phone or } \\
\text { mobile device } \\
\text { to read online. }\end{array}$ \\
\hline
\end{tabular}

A recent empirical study on food shortage in South African urban townships indicates that food shortage embodies multi-faceted aspects with broader social implications, such as the sense of personal dignity, the ability to openly associate with others and a loss of self-identity. It is argued that the parables of Jesus, when read as symbols of social transformation, provide a critique on food insecurity systems in urban townships. It is proposed that the parables of Jesus serve as the conduits for a societal and perhaps ecclesial reorientation with regard to the conditions of hunger, in the light of the vision and values of the kingdom of God.

\section{Introduction}

The aim of this article is to determine the use of some of the parables of Jesus as transformative interpretive instruments of food shortage in South African urban townships. ${ }^{1}$ The parables of Jesus serve as means of mediating personal and social transformation as envisaged by the kingdom of God. In order to reach the stated objectives, a sample of 360 township residents across the South Western Townships (Soweto) and Pretoria, comprising teenagers, youth and adults, were invited to participate in the study. ${ }^{2}$

Attention is given to a social-scientific reading of the parables of the historical Jesus, focusing on the social transformative intention of Jesus' parables. It is argued that the parables can be seen as 'markers of transformation', also when it comes to providing food security for poor and vulnerable households in South African urban townships.

\section{Reading lens}

The history of the interpretation of the parables can broadly be divided into three periods. In the premodern period - starting with the time of the writing of the gospels up to and including the Reformation - the parables were interpreted as allegorical moralisms. In the second period of parable interpretation (modern period), the focus on the kingdom of God as an eschatological expression dominated parable research, and in most cases, the parables were interpreted as apocalyptic symbols. This interpretation resulted in a metaphysical one-sidedness; the kingdom of God was seen as something 'out there'. Recently, we have seen a 'material turn' in parable research, where special attention is given to Mediterranean anthropology, stressing the key first-century Mediterranean values of honour and shame, limited good, personality, purity and pollution, and institutions of exchange such as patronage, euergetism and clientism. ${ }^{3}$ In this approach, an attempt is made to understand the parables inside their own world (historical context) ${ }^{4}$ as stories that proclaimed a new world and time, which challenged and reversed the hearer's world, empowering them to life and action (Crossan 1973:36). Or, as put by Herzog, the parables of Jesus is a 'form of social analysis', exploring 'how human beings could respond to break the spiral of violence and cycle of poverty created by exploitation and oppression' (Herzog 1994:3). Understood from this perspective, the parables of Jesus can be seen as symbols of social transformation.

Van Eck's interpretation of the parables of Jesus is an example of the material turn in parable interpretation, especially focusing on the parables as symbols of social transformation.

1.This article represents a reworked version of aspects from the PhD dissertation of Meshack Mandla Mashinini, titled The parables of Jesus as critique on food security systems for vulnerable households in urban townships, in the Department of New Testament Studies, University of Pretoria, with Prof. Dr Ernest van Eck as supervisor.

2.Information was ascertained through a questionnaire covering quantitative and qualitative instruments analysed using the Statistical Package for Social Science.

3.The benefit of using these models (reading scenarios) developed from cross-cultural anthropology is that they provide the modern reader with insights into the contrasting attitudes and values of first-century Palestinian societies from those of contemporary readers (Bidnell 2012:19). It is, as put by Oakman, to use the 'known to illuminate the unknown' (Oakman 2008:11).

4.'The text belongs to a specific world ... That world is first-century Palestine, and it forms part of the nexus in which the narrative operates and which is taken up into the text and transformed into the narrative. It informs the repertoire, the conventions, world view, ideologies, and stereotypes active in the text' (Scott 1989:76). 
In his reading of the parables, Van Eck takes the following as points of departure (see Van Eck 2009a:1-12): Firstly, the parables are interpreted in terms of the first-century Palestinian socio-cultural, political, economic and religious realities of the historical Jesus (27-30 CE), and not in terms of their respective textual contexts in the gospels. ${ }^{5}$ Secondly, in an effort to avoid the fallacies of ethnocentrism and anachronism, the cultural values and social dynamics of the social world of Jesus and his hearers are taken seriously by employing social-scientific criticism as exegetical approach. Thirdly, where applicable, available documented papyri are used to identify the possible social realities and practices (cultural scripts) evoked by each parable. In Jesus' parables, the central theme was the non-apocalyptic kingdom of God as a present reality. Every part of the kingdom proclaimed by Jesus did not point to 'the future soon, but the present now of the kingdom of God' (Crossan 2012:126; emphasis in original). Flowing from this, the parables of Jesus were not stories about God (theocentric), but stories about God's kingdom (Hultgren 2000:10). ${ }^{6}$ Jesus' parables, in the seventh place, are atypical stories, stories which subverted the dominant cultural and religious values of his world. His parables cut against the social and religious grain of his day, went against the expected and acceptable, surprised and shocked, and questioned the status quo; it proclaimed the kingdom of God vis-à-vis the suppressing kingdoms of Rome and the Temple elite.

A material reading of the parables, from these vantage points, emphasises Jesus' 'pastoral act of prophetic imagination' (Brueggemann 1986:97) that speaks of human solidarity against the Temple ideology of exclusion and social injustice, confirming the present and emerging reality of the kingdom of God. ${ }^{7}$ Jesus' alternative vision included the socially impure (e.g. the lame, the blind, cripples, lepers and women) and pictured a world in which everybody have enough to live with dignity. This vision of Jesus, as will be indicated below, is encapsulated in many of his parables, exposing the indignity of social marginalisation (Gutiérrez 1973:287). Jesus' position on social justice stood against a 'systemic pattern of abuse', directed at the peasantry. ${ }^{8}$ Many peasants, because of inter alia taxes, rent and tithes, lived below a level

5.The situation of the peasantry in Palestine in the time of Jesus can briefly be summarized as follows: Taxation was exploitative. Rome assessed its tribute and then left Antipas and the temple elite free to exploit the land to whatever degree they saw fit. Food and debt were a constant problem. Rising indebtedness lead to the loss of fit. Food and debt were a constant problem. Rising indebtedness lead to the loss of land (which had been the base of the peasant's subsistence), as well as the loss of the peasant's place in the traditional social structure. By using unconventional means, the elite in Galilee and Judaea became the controlling force of most private land. Small peasant farmers were increasingly replaced by large estates owned by the powerful and exploiting elite. In Galilee, especially, agriculture was commercialized which in turn lead to a monetisation of the economy. All this left the peasantry on the edge of destitution, and often over the edge (Van Eck 2009a:2-4). See also Borg (2006:227)

6.Or, as put by Herzog (1994:3): '[T]he parables were not earthly stories with heavenly meanings, but earthly stories with heavy meanings.' They are stories about 'the gory details of how oppression served the interests of a ruling class', exploring how human beings could break the spiral of violence and cycle of poverty of an oppressed society created by the power and privilege of the elite (including the temple authorities).

7.See Tutu (2000:214), in following Teilhard de Chardin, who accentuates the transformative and inclusive vision of the kingdom of God as an emerging reality that 'is being slowly engendered'.

8.Salazar and Doxtader (2007:7) correctly state that 'systemic patterns of abuse' include 'the gross human rights violation mediated by food shortage'. of subsistence and battled to live a dignified life. Many became part of a process of 'downward mobility'; as in almost all cases, systemic exploitation led to systemic exclusion' (see Terreblanche 2002:3). This is the world that was (and is) challenged by Jesus' parables; promoting 'restorative justice' in the place of 'retributive justice'. ${ }^{10}$

\section{Food shortage in vulnerable households in urban townships}

During 2014-2015, empirical research regarding food shortage was conducted at a grassroots level in urban townships in Gauteng, primarily in Soweto with 320 (90\%) households, and on a limited scale, $40(10 \%)$ persons were interviewed in some areas of Pretoria (see Mashinini 2015:93-99). This resulted in an overall participation of 360 persons within family settings. The conceptual framework of this research was to provide space for the interviewees to articulate opinions and perceptions with respect to four definitive categories that relate to food shortage, namely self-consciousness, material possessions, social relations and issues of spirituality. The participants were invited to participate on a voluntary basis. It was hoped that the involvement of both the youth and adult participants, including pensioners, would enable the research to draw a balanced picture of the actual experiences of vulnerability. There were no specific criteria to determine who would be permitted to be part of the study or not, other than the precondition that one had to reside in the targeted community.

The interviews were undertaken based on especially two minimal requirements: participants must have had personal exposure to food shortage, both in the family setting and individual capacity and had to be older than 15 years of age (with no upper limit). The latter requirement aimed at determining the extent of child-headed households. There was no upper age limit because of the intention to get figures of pensioners who are supporting their families with their monthly pension grant.

The study was conducted by using a questionnaire that inter alia included a self-report checklist containing quantitative and qualitative questions (see Mashinini 2015:281-287). The questions focused on the experience of food shortage, the effect it has on relationships with others and the relationship with oneself (dignity), as well as the effect food shortage has on one's relationship with God/Creator/Supreme Being. Space was also provided for the participants to make qualitative remarks, using their mother tongue if they wanted to do so. The quantitative results were captured, analysed and integrated into the body material of the study.

9.Many peasants, because of taxes, rent and tithes, first lost their ancestral land became tenants, then day labourers and finally ended up as part of the expendables of society (e.g. beggars like Lazarus) (see Van Eck 2009b:8).

10.The notion of 'restorative justice' is propounded by Desmond Tutu as a contribution of 'traditional African jurisprudence'. Tutu perceives restorative justice as the 'healing of breaches, the redressing of imbalances, and the restoration of broken relationships' in mutual recognition of the dignity of the perpetrator and the relationships' in mutual recognition of the dignity of the perpetrator and the
sinned against (Tutu 2000:51). See also Crossan (2010:14), who defines distributive justice as 'everyone should have enough'. 
A summary of the results of the survey looks as follows (see Mashinini 2015:100-151):

- Sixty seven per cent of participants reported that because of food shortage, they have lost the respect of others. This reflects a deficit of respect embedded in society. ${ }^{11}$ The survey also indicates that food shortage embodies multi-faceted aspects with broader social implications ${ }^{12}$ and that its restoration should be manifested in social relations. ${ }^{13}$

- Sixty four per cent of participants stated that food shortage undermines their sense of personal dignity. These figures show that food shortage inflicts deep wounds and pain in the space of personal identity of those living with hunger. ${ }^{14}$

- Sixty two per cent of participants felt that their desperate condition affects their ability to openly associate with others. The implication is that the values of Ubuntu-botho are difficult to be practised in the community and that in a certain sense, food shortage impinges on values of Ubuntu-botho. ${ }^{15}$

11.See (Brown 1971:562), who argues that, in sociological terms, the loss of respect refers to the connotation of 'shame' that 'exposes one to the ridicule of society'.

12.The multiplicity of experiences of hunger resemble 'the multi-layered experiences of the South Africa story' recorded in the testimonies of victims of human rights violations before the Truth and Reconciliation Commission (TRC). The testimonies were categorised as personal, narrative, social, and healing and restorative truth. The testimonies on food shortage bear the marks of the TRC's four notions of truth (see Truth and Reconciliation Commission 1998, Concepts and Principles, Article 36).

13.See the minority judgement by Justice Albie Sachs in The Dikoko Case before the Constitutional Court where Sachs calls for justice 'to restore a person's public honour while assuaging interpersonal trauma and healing social wounds' (see Sachs 2006, paragraphs 107-117). This has reference to personalised trauma lived by those dealing with food shortage.

14.Küng (1990:1) places the essence of being human in the centre of policy formulations, which affirms human dignity. Hence, experiencing hunger becomes factor that 'hinders men and women in their identity, sense of meaning and sense of dignity, and thus does not allow them to attain to a meaningful and fruitful existence'. Dealing with the pain of losing one's dignity is articulated by the framework of the 'healing and restorative truth' of the Truth and Reconciliation Commission (see Truth and Reconciliation Commission, 1998, Concepts and Principles, Articles 43-45). A similar position on the centrality of human dignity in social relations is attested by the Constitutional Court judgement in the Hoffman Case. The Hoffman Case by the Case. The result of the 列 work as a steward because of his HIV (SAA) to Justice Sandile Ngcobo, in conveyin the majority opinon of the Court, ruled aganst the SAA in favour of Mr Hoffman. In his argument, Justice Ngcobo referred to the question of human dignity as fundamental right. He alluded that our Constitution demands the granting of 'equal dignity' to all citizens. He noted that 'the inherent dignity' of all is a prerequisite for the greater good of society. Due recognition and protection of human dignity serves as a precautionary measure against 'all forms of discrimination'. The judgement confronted the reality of 'systematic disadvantage and discrimination' as constituting the impairment of dignity of Mr Hoffman (see Constitutional Court, 2000). This case has a bearing on the issues of food shortage and its subsequent impact on the loss of personal dignity of the affected. It speaks of the impairment of both the 'inherent' and 'equal' dignity of the hungry. The court has opened itself to perceive the reality of belonging to the 'most vulnerable groups in our society'. However the judgement missed to recognise that social groups in our society'. However, the judgement missed to recognise that socia vulnerability is not just a 'group dynamic' reality. It is a social and a class construct. Those referred to as the "vulnerable' have become a distinct class and have a claim The significant social class with given specificity of social dislocation. However, the case clearly points to the conceptual framework of human dignity as a given right. Sach (2009:213) holds the view that South Africa's constitution is premised on principle of human dignity, freedom and equality before the law. The courts must regard the 'respect for human dignity' to be the centrifugal point of reference in our urisprudence, particularly in conditions 'where human dignity is most at risk' Similar sentiments characterised the recently held United Nations third 'Financing for Development' summit, which was held in Ethiopia in July 2015. The summit deliberated on the new Sustainable Development Goals - 2015-2013 (SDGs). The first three indicators of SDGs seek the eradication of poverty and hunger, seek to achieve food security and better nutrition, as well as to 'promote the well-being for all at all ages'. The question of human dignity in Africa hinges on the provision of adequate budgetary systems and targeted policy intervention informed by the new agenda for social development (Kabukuru 2015:10-16).

15.The difficulty of opening up is highlighted in the Soombramoney Case. Mr Soombramoney approached the Constitutional Court to seek redress for access to medical treatment with dialysis. The ruling of the Court was delivered by the then President of the Court, Justice P. Chaskalson. In a concurring judgement, Justice
- Sixty one per cent of participants reported that food shortage interferes with them having meaningful relationships with others. The figures point to a deep loss of self-identity in a country with a constitution that celebrates racial and cultural diversity. ${ }^{16}$

\section{The parables of Jesus as symbols of social transformation in relation to food shortage}

The conducted empirical study in the identified urban townships indicated that those who are vulnerable to food shortage have lost the respect of their respective communities, and, because of ridicule, are experiencing shame. Food shortage also impacts on social relations and undermines a sense of personal dignity. Addressing food shortage thus entails much more than mere access to food. It also includes the restoration of a person's public honour, the assuaging of interpersonal trauma and the healing of social wounds (Sachs 2006, paragraphs 107-117), the restoration of dignity (Küng1990:1) and the challenge to maintain open and accountable social relationships (human interdependence with a social interdependence; Sachs 1997:189).

The parables of Jesus, as symbols of social transformation, address some of the societal issues that go hand in hand with food shortage. The parable of the Sower (Mk 4:3b-8), first of all, shows the reader how to align oneself with the vision and values of the kingdom in the context of exploitation, and that by sharing, everyone will have enough (Van Eck 2014:1-10), while the parable of the Minas (Lk 19:12b-24, 27) addresses the question of exploitation and how to wage protest against such conditions by not partaking in exploitative practices (Van Eck 2011a:1-11). The parable of the Unmerciful Servant (Mt 18:23-33) brings to our attention Jesus' critique of privilege, status and honour, and promotes 'generalised reciprocity' as a basis for human interaction based on mutual respect (Van Eck 2015a:1-11). This is also the case in the parable of the Feast (Lk 14:16b-23), a story of Jesus in which the socially marginalised are treated as honoured guests at an abundant table (Van Eck 2013:1-14). The parable of the Rich man and Lazarus (Lk 16:19-26) depicts the opposite.

(footnote 15 continues ...)

Sachs located Mr Soombramoney's issues on the basis of communal interaction. His reading of Soombramoney's contentions highlighted the challenges of maintainin open and accountable social relationships. Social and economic obstacles to open and accountable social relationships. Social and economic obstacles to penness to others define the relations constructed by food, shortage. Hence, interdependence' quality. The former aspect of 'dependence' demands a conscious reliance of persons to each other. The 'social interdependence' demands social systems to determine how human needs are addressed. We need to quantify the quality of human interdependence' and 'social interdependence' affected by food shortage (see Sachs 1997:189)

16. Food shortage has given birth to a diversity of vulnerability. The diversity of brokenness defined by food shortage is well capsulated in Baumeister's (holocaust survivor) notion of the 'magnitude gap'. Baumeister's concept of differentiation points to a 'discrepancy between two quiet different and irreconcilable positions'. Food shortage creates a 'discrepancy' for affected families and individuals to have healthy relations with oneself and the community at large. The inability to relate to healthy relations with oneser and the community at large. The inability to relate to ( ( relations in our country. The appreciation of locality of vulnerability and its subjectivity broadens the impact of hunger as constructed by interests of privilege subjectivity broadens the impact of hunger as constructed by interests of privilege (see Truth and Reconciliation Commission 1998,
Human Rights, Extract Four, articles 47-50). 
This parable is a kingdom statement against the widening gap of inequality and declares that if no measures are taken to eradicate inequalities, the kingdom will never become a reality (Van Eck 2009b:1-11). The parable of the Merchant (Mt 13:45-46), penultimately, tells a story of how a previous exploiter of the poor (outsider) becomes an insider who embraces the values of the kingdom to the benefit of the exploited and marginalised poor (Van Eck 2015b:1-8). Finally, the parable of the Friend at Midnight (Lk 11:5-8) advocates a conduct in which neighbours should meet each other's needs without expecting anything in return (Van Eck 2011b:1-10).

\section{The parable of the Sower (Mk 4:3b-8) ${ }^{17}$}

In the Sower, Jesus tells a story about a peasant farmer who is sowing his land. The peasants who owned small plots in Judaea and Galilee believed that the land belonged to Yahweh were given to them by Yahweh, and they had the privilege to work the land as tenants. Yahweh promised that the land will yield its fruit and that there will be no hunger, and, as long as they obey His commandments, the land will stay in their and their offspring's possession, a land in which they will eat bread without scarcity and will lack nothing. With this belief, the peasant small holders worked the land, the main crops being wheat, maize, olives, figs and grapes, and were able to support a relatively comfortable lifestyle.

However, outsiders were now enjoying the fruit of this land. The largest part of the best agricultural land was owned by Romans, Herod Antipas, the veterans of Herod the Great's armies, the Herodians and the temple elite. The peasantry, on the other hand, who still owned land in most cases had to be content with a shortage of good cultivatable land, minimal land size, thorns and roads at the edge of small fields, and rocky patches because of a shortage of ploughland. Numismatic evidence, especially from the period of Augustus, communicated that the land belonged to the Caesar, and not to God. According to this Roman propaganda, the fruit of the land belongs to the rulers of the country. Land, in the time of Jesus, thus embodied certain social realities.

When Jesus told the parable, starting with the phrase 'a sower went out to sow', the peasants exactly knew what will happen to the harvest. Because the elite believed that the harvest belonged to them, tribute will be involved, taxes and rents will have to be paid and the temple elite will also take their share. Little will be left for the one who is working the land. These, after all, were the social realities of Galilee in 27-30 CE.

In the parable, the one part of the seed that falls on the road symbolises that part of the harvest where tax, tribute and rents were paid in kind or, where taxes or rents were exacted in money, peasants had to make use of roads to transport their goods to local markets to sell to wholesale merchants. Roads, for the peasant farmer, symbolised pressure and exploitation, silos and vaults, trade and markets. Roads, in short, assisted the elite to siphon wealth out of the hands of peasant farmers. ${ }^{18}$ The second part of the seed that falls on rocky places most probably indicates that the farmer is working the land where the abundance of rocks is the result of the exploitation of the peasantry by the elite who expropriated most of the best land. Because of this, a second part of the harvest is also lost, even before sowing starts - a part of the harvest that is toiled for will reap no gain; it already belongs to elite. The third part of the seeds falls among the thorns. The thorns will grow up and choke the seed, it will yield no grain, at least not for the peasant farmer working the land. In the Old Testament, thorns are a common metaphor used to describe the wicked. In the case of the parable, the thorns most probably refer to the Temple elite who also, in terms of tithes and offerings, claimed their part of the harvest. The fact that a part of the seed falls among thorns thus reveals its inevitable fate; a part of the harvest will grow, but choked by the temple elite.

But all is not lost. The Sower is not only about what happens with the harvest, but also about what can happen with the harvest. Many seeds (ö $\lambda \lambda \alpha$; Mark 4:8) fall on good soil, grow and produce a crop that yields a harvest of 30-, 60- and 100-fold; the part of the harvest that belongs to the peasant farmer. Why does this part of the seed sown yield such an abundant crop? Because this is what can happen when the harvest is shared with those who also barely live above a level of subsistence. Large parts of the harvest go to Rome, the Herodian and temple elite, but a part is left that has the potential to make the kingdom visible. When the 'leftover' yield of the harvest is shared by supporting others in need, the kingdom becomes visible. As such, the kingdom is good news to the poor ( $\operatorname{Lk} 4: 18)$; the place where the hungry will have a feast ( $Q$ 6:21); where those who weep will laugh (Q 6:21); where bread is provided day by day (Q 11:3); where everyone who asks receives (Q 11:10); a place where one does not have to worry about what one is going to eat ( $Q 12: 22)$.

Read from this perspective, the Sower envisions a different, and possible, reality for its hearers; it awakens the hearer in the present world to an altered experience of reality. As such, the Sower presents a critical evaluation of the conditions of the indignity of hunger, premised on the contemptuous attitudes of the elite against the vulnerable. The restoration of the dignity of the vulnerable takes place in their willingness to be transformed by the values of the kingdom that points to reaching out to others.

\section{The parable of the Minas (Lk 19:12b-24, 27) $)^{19}$}

The parable of the Minas is not a parable about two good slaves and one bad slave, but rather a parable of two bad slaves and one good slave. The parable is also about the

18.This metaphoric understanding of the part of the harvest that will go to the elite is

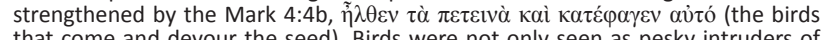
that come and devour the seed). Birds were not only seen as pesky intruders of cultivated lands, and the natural enemies of the sown, but also served as the primary symbol of Roman divine favour and election, Roman military might and concomitantly of Roman imperial ideology (especially the eagle). Thus, as in 1 sower. A part of the harvest will be devoured by the elite.

19.For a detailed analysis of the parable of the Minas (see Van Eck 2011a:8-10). Scholarly contributions that were used in this reading are referenced in the article. 
exploitative normalcies that were part and parcel of firstcentury Palestine elite who, on a constant basis, were looking for more honour, power and privilege and used their power to exploit the poor. Moreover, it is a story about a slave who refused to partake in this exploitation, in this case, lending money at very high rates to peasants who already were in dire straits.

The parable, indirectly at least, addresses the question of how non-elites can negotiate a world of material domination that appropriates their agricultural production and labour by excessive taxation. One approach is to proceed like the first two slaves, legitimating the domination of the elite. Or one can act like the third slave in refusing to partake in domination and exploitation. How does the third slave do this? Firstly, he ties the mina in a cloth to protect the existing share of the owner. Secondly, when confronted by his master, he does not characterise his master as a hard man to justify his fear and consequent inactivity with the mina. He rather takes the attitude of: 'I knew I had to be careful, and I have been' (Rohrbaugh 1993:37). How would the nobleman have heard this? Most probably in the sense of 'Master, I have so much respect for you (I am honouring you), that I did not want to take a chance with your money. I did what I thought was the honourable thing to do, that is, to protect what belongs to you'. But what did the peasants, who most probably were part of the audience when Jesus told the parable, hear? Most probably: 'You are a thief, and I am not willing to be part of what you are doing!'

From this perspective, the Minas reflects Jesus' critique of the elite's entitlement to honour, power and privilege by exploiting the peasantry. It points to the kingdom vision against 'a culture of shame and of guilt' (Krog 1998:262) in the surprise acts of the third servant in refusing to advance exploitation. As such, the parable demands creativity on challenging the powerful and calls on the 'haves' to share with those who do not have.

\section{The parable of Unmerciful Servant $\left(\mathrm{Mt}\right.$ 18:23-33) ${ }^{20}$}

In the parable Jesus tells a story about a king who wishes to settle his accounts. A servant who cannot pay is brought before him, and the king orders the servant to be sold with his family and his belongings to cover the outstanding debt. The relationship between the king and the servant, viewed in terms of the cultural world that produced the parable, is that of patron and client. Patronage and clientism was part and parcel of aristocratic (advanced agrarian) societies like the first-century Mediterranean world. These relationships were socially fixed, based on a strong element of inequality and difference in power, were voluntary and reciprocal, focused on honour and respect and were held together by loyalty. The basic structure of these relationships was an exchange of different and very unequal resources. By granting the servant a loan, the king favoured the servant by giving him access to economic and political resources otherwise not available.
By accepting the loan, the servant promised to pay back the loan as and when determined by the king. In the parable, this moment had now arrived. The client (servant) now has the opportunity to show his loyalty towards his patron.

When the servant cannot pay his debt, the king's first decision is to sell the servant to make up for his loss. However, the servant desperately begs the king to have patience until he is able to pay his debt. The king then, because of this request and out of compassion, decides to overturn his initial decision and releases the debt of the servant.

Why did the king release the debt of the servant? In patronclient relationships, it was not only expected of the client to behave in specific ways. Because patron-client relationships involved a strong element of personal obligation, it was expected of patrons to show generosity and mercy. On the basis of such mercy, the king forgives the debt, but also because of his desire for repute and honour. Because the king expected that the servant would enhance his reputation after the release of his debt on an ongoing basis by repeated public praise of his merciful patron, the king released his debt.

For the modern interpreter of the parable the release of the debt by the patron-king, because of personal obligation and the search for public honour, seems incredible. Documented papyri, however, indicate that it was normal practice for kings to release debt as acts of royal care for subjects with the aim to acquire honour. Thus, releasing of the debt of the servant is not a surprise in the parable.

The scene between the two servants in the parable, and the decision of the first servant not to release a much smaller debt, can also be understood against the social realia evoked by documented papyri. Kings normally expected, when they released debt, for their subjects to release the debt of other subjects. Such release of debt would have honoured the king by proclaiming his release of debt openly and would have been seen as an act of obedience and personal obligation as client of the king, assimilating his behaviour by releasing the debt of his fellow servant.

This does not happen, and by his decision, the servant instead shames the king. The other servants, most probably also clients of the king acting inter alia as his informers, then report (gossip) what happened to the king, whereafter the first servant is summoned. Then comes the surprise in the parable. Thus far, the story in the parable developed as expected in terms of the cultural experience of its hearers. Kings forgive debt in search of honour, and clients reciprocate accordingly. Therefore, when the first servant did not reciprocate as was expected, the king had to defend his honour, power and privilege. In a world where honour and power were core values, it was considered as shameful not to defend one's honour and power. But this is exactly what the king does. Totally unexpected, he does not react with a defence of honour, or in the first servant's typical and socially accepted ruthless way. This is clear from his words in Matthew 18:33: When someone asks for the release of his debt, you show 
mercy without expecting a socially prescribed response. Honour does not lie in the eye of the beholder, but in the act itself. The release of debt should be given altruistically, that is, not in terms of balanced reciprocity, but in terms of general reciprocity. When this happens, the basileia of God is visible. To act differently, makes one wicked.

Read from this perspective, Jesus uses the parable to question first-century Mediterranean social relations based on balanced reciprocity and the pivotal value of honour. A world based on the value of honour is dominated by the powerful and ensures the preservation of privileged positions and power, and, because it is fundamentally unbalanced, leads to exploitation and debt. This world is not the basileia. On the contrary, the basileia of God is present where debt release, in the act itself, is the honourable thing to do.

\section{The parable of the Feast (Lk 14:16b-23) ${ }^{21}$}

In the parable of the Feast, a wealthy urban elite invite other elites to a feast. Because, in the time of Jesus, likes only ate with likes (people with the same social standing, status and honour rating), it can be supposed that the invitees in the parable were also part of the elite who occupied the walledoff centre of the city.

The invitees, however, as well as the many invited, decline the invitation. No one shows up. This most probably was the result of gossip; a social game that was part of the world of the parable that served as boundary maintenance. In the world of the parable, meals were occasions that carried significant social coding and identity formation. The host saw himself as a peer of and equal to his invitees or hoped that by accepting, his guests will affirm his current honour-rating or rating he aspired to. But he is shunned. For some reason, attendance was socially inappropriate.

Then, the surprise in the parable. When the slave reports back to the host that not one of the invited elite was going to attend his feast, the wealthy elite decide to be a different kind of patron, a patron who is not interested in honour-ratings or balanced reciprocity, that is, what he can get out of inviting people to his feast. He sends his slave to invite people living in the wider streets and squares and the narrow streets and alleys, that is, those who live inside the city between the inner and outer walls. And when the slave reports back that there is still room for more, he sends his slave to invite those in the roads and country lanes or hedges, the socially impure (expendables) living outside the city walls to fill up his table.

Thus, while the urban elite first invited took significant steps to avoid contact with those living outside the inner and outer walls of the city except to obtain goods and services, the host socialises and eats with them. By this, the host abandons the ever-present competition for acquired honour in the firstcentury Mediterranean world, replaces balanced reciprocity (quid pro quo) with generalised reciprocity (giving without expecting anything back) and declares the purity system 21. For a detailed analysis of the Feast, and sources used, see Van Eck (2013:7-12). which deems some as socially and ritually (culturally) impure null and void. All walls have been broken down, and the world is turned upside down. In the kingdom, wealthy patrons are real patrons when they act like the host: giving to those who cannot give back, breaking down physical (walls) and manmade boundaries (purity and pollution) and treating everybody as family (generalised reciprocity), without being afraid of being shamed.

\section{The parable of the Rich man and Lazarus (Lk 16:19-26) $^{22}$}

The parable of the Rich man and Lazarus is a story about the great class disparity in first-century Palestine, about the divide between the urban elite who controlled all the wealth, power and privilege, and the exploited rural peasantry who lived in the narrow margin between famine and subsistence. In the parable, the elite is represented by the rich man. Because he was able to maintain his wealth, he was a man of honour. To enhance his honour and status, he feasted every day, most probably with other elites that stood with him in patron-client relationships. Being part of the elite, he also competed for clients among the poor and the peasantry. These patron-client relationships put him in a position to control more and more land, produce and labour.

At his gate, one of the products of his exploitation, Lazarus (who represents the exploited peasantry), spends his days. Lazarus had become one of the expendables of the society the rich man and the other elite created. Lazarus was no longer of any use to the rich man. Because he was put there every day, he could not really beg or take part in the daily salutation of the patron. He was no occasion for almsgiving or the enhancement of honour. Nothing could be gained by making Lazarus a client, even in terms of negative reciprocity, and to show hospitium to him (e.g. looking after his sores) would have made Lazarus his equal. This, of course, would have meant a loss of honour. To him, Lazarus was expendable in every sense of the word.

In the parable, the name Lazarus (God helps) is not accidental. It typifies the way in which Jesus sided with the poor, the expendables and the socially impure during his day. In a situation where Jesus very well knew that the exploiting rich were only becoming richer and the poor poorer, Jesus' concern for the poor is not surprising. He congratulated the poor and the hungry, damned the rich and those who were well-fed at the cost of the poor and exhorted the rich to sell their possessions and give to the poor. He encouraged hosts to invite the poor, crippled, lame and the blind who cannot repay them, to love their enemies, to do good and to pray for their abusers, to lend to others expecting nothing in return, to treat people in the same way as they would want to be treated and to forgive the debt of others. Jesus even tried to turn the hearts of the powerful to the powerless and dishonoured poor and ate indiscriminatingly with the so-called 'sinners' and healed the sick. From this, it becomes clear that Jesus'

22. For a detailed analysis of the parable of the Rich man and Lazarus, see Van Eck (2009b:5-9). Scholarly contributions that were used in this reading are referenced in the article. 
sympathies indeed lay with the poor. There was help, after all, for Lazarus - especially in a kingdom where God was the patron and not the ruling aristocratic elite. Where God is patron, the gate is crossed. However, this was neither the kind of patron the rich man was nor the way in which he acted. Nothing prevented him from doing otherwise. The gate was there, it even belonged to him. But he did not cross it - simply because there was nothing in it for him. He could only lose some honour.

When the rich man dies, he has the opportunity of viewing the way things are from the other side of the gate. He is confronted with the kind of patronage towards, and solidarity with, the poor and destitute Jesus advocated. Abraham, the example par excellence of hospitality in the Old Testament, clearly embodies Jesus' attitude towards the poor. But Abraham is not willing to help; the gate between Abraham and the rich man cannot be opened. It cannot be crossed. It has been closed forever.

When patrons, who have in abundance, do not cross the gate to the poor, a society is created wherein a chasm so great is brought into existence between rich (elite) and poor (the peasantry) that it cannot be crossed. The worlds of the urban elite and the peasantry drift so far apart that the gap between them eventually cannot be closed. Go through the gate while you can. Just as unthinkable as it is for Abraham not to do what he can, it is also unthinkable for those who can help. Abraham, being the example of hospitality, had no reason to turn his back on the rich man. The same holds for the rich man - nothing stood in the way of his helping Lazarus. It was not impossible to help Lazarus. However, the protection of his status and honour made it impossible. And when this happens, nobody can become part of the kingdom - neither Lazarus nor the rich man.

\section{The parable of the Merchant (Mt 13:45-46) ${ }^{23}$}

In the parable of the Merchant, the kingdom is likened to the actions of a merchant. For the first hearers of the parable, most probably peasants in Galilee, this depiction of the kingdom must have been shocking. Because of the perception of limited good in advanced agrarian societies, and the conviction that production was primarily for use rather than exchange (i.e., supporting immediate families and the village), the profits made by merchants were perceived as a form of usury and unnatural. Their trade was socially destructive and a threat to the community. In the eyes of the peasantry, merchants were evil and considered as being thieves. The fact that merchants had to make use of ships for their import-export trade and that most shipowners were non-Jewish added to this negative perception. Merchants owned large parts of land and were part of the apparatus of the political ancient economy of the first-century Roman Empire. They assisted the movement of goods accumulated through forced extraction of goods, cash crops

\footnotetext{
23. For a detailed analysis of the parable of the Merchant, and sources used see Van Eck (2015b:7-8).
}

and commercial farming. As such, merchants played a major role in the transformation of the peasantry's daily lives that focused on subsistence, and not commercial trade.

Thus, the shock in the parable; the kingdom is like the actions of a merchant. But how can the merchant in the parable be a positive symbol for the kingdom? In what he does. On his travels, he finds a pearl. The value of the pearl is so high that he has to sell everything he owns to buy it, and by doing this, he stopped being a merchant. He sold all he owned and took leave of the trade he practised. Taking leave of the despised trade he practised, the merchant now was part of the kingdom. No more trading, including usury, will take place. In the kingdom, there is no place for usury, actions that are destructive and a threat to the community, or for being part of the apparatus of the exploitative political ancient economy of the first-century Roman Empire. Being part of the kingdom, one also cannot support the forced extraction of goods, cash crops and commercial farming to the detriment of those who already lived close to or below a level of subsistence. In short: A merchant stopped being a merchant. An outsider has become an insider, and insiders act according to kingdom principles. Read from this perspective, Jesus, with this short parable, criticised the exploitative political economy of his day. Another option was available, typified by the actions of a despised merchant.

\section{The parable of the Friend at Midnight (Lk 11:5-8) $)^{24}$}

The situation of the peasantry in Palestine in the time of Jesus was one of destitution. Taxation was exploitative, and the elite lived at the expense of the non-elite - shaping the social experience of the peasantry, determining their quality of life, exercising power, controlling wealth and enjoying high status in the process. Social control was built on fear, and the relationship between the ruling elite and the ruled peasantry was one of power and exploitation. All this left the peasantry on the edge of destitution, and often over the edge.

This situation had a negative impact on traditional village life and traditional village values - village families were hard-pressed to provide their own families with something to eat and were under tremendous stress to survive. This situation impacted heavily on the relationships between families; some villagers, who previously felt responsible for helping their neighbours in times of shortage, were no longer willing to do so. In an effort to survive, some peasants started to mimic their Roman overlords and the Jewish temple elite by setting up patron-client relationships with co-peasants and villagers; some of the exploited became exploiters themselves - self-interest turned the 'own' into the 'other'. ${ }^{25}$

24.For a detailed analysis of the Friend at Midnight, and scholarly sources used, see Van Eck (2011b:10-12).

25.Food shortage in urban townships has the same negative impact on social relations. Its ripple effects result in disjointed 'social networks', evidenced by financial constraints, unemployment and dropping out of school for most of the affected youths. The reality of food shortage are creating a schism in black families and communities, in that family and societal relationships are defined by the ability or inability of each family to provide enough food for its members (see Truth and or inability of each family to provide enough food for its members (see Truth and
Reconciliation Commission 1998, Consequences of the Violations of Human Rights, Extract Four, articles 90-91). 
The scarcity of goods especially challenged the traditional value of hospitality. Some villagers were no longer willing to subscribe to this sacred duty and village value.

The parable of the Friend at Midnight presumes these socioeconomic conditions. A peasant villager, in the middle of the night, has an unexpected visitor who is his friend. Because he is his friend, the host considers him as family. The visitor knew he could count on his host, because both of them (being friends) were concerned for each other's honour. His friend would supply whatever was needed to uphold his honour. Friendship, after all, meant that friends could rely on one another; it implied true commitment, especially when a friend was in need. Moreover, hospitality was extended to friends as a normalcy; it was part of friendship to offer hospitality.

However, the host had nothing to offer his friend to eat. But this was not a problem. An unexpected guest was considered to be a guest of the entire village; the entire village was responsible to put a meal on the table for his friend and because of this he could call on others in the village to help him. $\mathrm{He}$, therefore, calls on his neighbour whose wife, according to the rotating schedule of their village, had baked bread in the community oven the previous morning.

In terms of the social values of friendship and hospitality in village life, the request of the host was nothing more than normal, a request that simply had to be met. However, the neighbour's reaction is negative. He is not willing to help as a friend, but he has an offer to make. Without any shame, he is willing to make a friend (the host) a client. He is willing to go for balanced reciprocity. He will give, but will call in the favour in future.

Thus, the villager is a 'bad' neighbour. Villagers regarded their friends and neighbours in the same way as they did their family - as kin. When neighbours are neighbours, in this sense, the kingdom becomes visible. However, when neighbours do not act as neighbours, like this villager, nothing of God's kingdom is visible. As such, the parable questions the shamelessness of the neighbour, his participation in a world created by the oppressing elite and his enforcement of the elite's oppressive mores by acting against his friend and neighbour. A just village and just neighbours would resist the moral corruption of the elite by refusing to treat one another as the elite hoped they would do. In short, the parable makes it clear that what is needed for peasant and village is to act with integrity; integrity that visualised a different world within a world of oppression and exploitation. When neighbours exploit neighbours, they are not part of the kingdom. This was not the way to act.

\section{Conclusion}

The peasantry in first-century Palestine worked the land with the aim to support their families. Under normal circumstances a life above the level of subsistence was possible. Because of the policies of the Roman client kings, and the Temple elite, others now were enjoying the fruit of this land. The largest part of the best agricultural land was owned by the elite. Taxation, rents and tithes were excessive, and the elite used their honour, power and privilege, to exploit the poor. This situation had a negative impact on traditional village life. Village families were hard-pressed to provide their own families with something to eat and were under tremendous stress to survive. This situation impacted heavily on the relationships between families; some villagers, who previously felt responsible for helping their neighbours in times of shortage, were no longer willing to do so. Being exploited and shamed, it was everyone for himself, and at times, peasant exploited other peasants to survive.

Food shortage, as the empirical study has indicated, is more than simply an empty stomach. Food shortage leads to personal trauma, such as the loss of dignity, self-respect and the respect of others. People living with food shortage are ashamed and are being exposed to the ridicule of society. Food shortage in urban townships especially has a negative impact on social relations. Its ripple effects result in disjointed social networks, financial constraints, unemployment and dropping out of school for most of the affected youths. The reality of food shortage is creating a schism in families and communities, in that family and societal relationships are defined by the ability or inability of each family to provide enough food for its members. Because of this, the current level of food shortage in urban townships is seen by some, because of certain systemic (political) patterns of abuse, as a gross human rights violation. This point cannot be emphasised enough. Food shortage does not simply relate to the lack of something to eat; where systemic patterns of abuse are present, food shortage is a gross human rights violation and a gross human dignity violation in the sense of God's kingdom.

In his parables, Jesus envisioned a different, and possible, reality. His parables, as symbols of social transformation, awakened its hearers to an altered experience of reality. When those who have share what they have with others, this reality becomes visible (the Sower and the Feast). When one is willing not to partake in the exploitation of others (the Minas and the Merchant) and is willing to challenge the powerful (the Minas), this reality becomes visible. When one is willing to show mercy without expecting something in return, this reality becomes visible (the Unmerciful Servant). When one is willing to open your table for the so-called expendables, this reality becomes visible (the Feast). However, when the gate stays closed (the Rich man and Lazarus), and when neighbours exploit neighbours (the Friend at Midnight), we partake in a world of spiralling food shortage and human indignity.

Practically, the above firstly implies that those who consider themselves as part of the kingdom should be willing to support others even with the little they have, and those who have more than they need should share in abundance with those in need. Secondly, participation in the exploitation 
of others, especially the weak and the hungry, should be opposed in any way possible. Creativity is needed to challenge the powerful who exploit others for their own benefit. Important here also is self-criticism; 'unconscious' participation in systemic violence should be made conscious. Thirdly, the alleviation of poverty and the restoration of the dignity of others should be practised altruistically; recognition (honour) and reciprocal expectations cannot play a part in addressing the needs of the weak and poor. Above all, whenever and wherever possible, an open table should be practised. In the kingdom, there is no place for closed gates and privileged space. What is needed is to be human and to be part of the human experience that can be called hope.

The restoration of the dignity of the vulnerable because of food shortage can take place in the willingness to be transformed by the values of the kingdom that points to reaching out to others. The inherent dignity of all is a prerequisite for the greater good of society, and the protection of human dignity serves as a precautionary measure against all forms of discrimination, including food shortage. This world is pictured in the parables of Jesus, a world in which everybody can have enough, a new way of being in a world riddled with social injustice and the exploitation of the weak to the benefit of the minority of elite.

\section{Acknowledgements Competing interests}

The authors declare that they have no financial or personal relationships, which may have inappropriately influenced them in writing this article.

\section{Author contributions}

This article represents a reworked version of aspects from the $\mathrm{PhD}$ dissertation of M.M.M. in the Department of New Testament Studies, University of Pretoria, with E.v.E. as supervisor.

\section{References}

Bidnell, D.R., 2012, A cultural-literal reading of Luke's parables, University of Birmingham, Birmingham.

Borg, M.J., 2006, Jesus: Uncovering the life, teachings, and relevance of a religious revolutionary, HarperCollins, New York.

Brown, C. (ed.), 1971, The new international dictionary of New Testament theology, Zondervan, Grand Rapids, MI.

Brueggemann, W., 1986, Hopeful imagination: Prophetic voices in exile, Fortress Press, Minneapolis, MN.

Constitutional Court, 2000, Hoffmann v South African Airways, viewed 26 October 2015, from http://www.saflii.org/za/cases/ZACC/2000/17.html
Crossan, J.D., 1973, In parables: The challenge of the historical Jesus, Harper \& Row, New York.

Crossan, J.D., 2010, The greatest prayer: Rediscovering the revolutionary message of the Lord's Prayer, HarperOne, New York.

Crossan, J.D., 2012, The power of parable: How fiction by Jesus became fiction about Jesus, HarperOne, New York.

Gutiérrez, G., 1973, A theology of liberation: History, politics, and salvation, Orbis Books, Maryknoll, NY.

Herzog, W.R., 1994, Parables as subversive speech: Jesus as pedagogue of the oppressed, Westminster John Knox Press, Louisville, KY.

Hultgren, A.J., 2000, The parables of Jesus: A commentary, William B. Eerdmans Publishing Company, Grand Rapids, MI. (The Bible in its World.)

Kabukuru, W., 2015, 'Obama homecoming inspires a nation', New African Magazine, 15 August, pp. 10-16.

Krog, A., 1998, Country of my skull: Guilt, sorrow, and the limits of forgiveness in the new South Africa, Three Rivers Press, New York.

Küng, H., 1990, Global responsibility: In search of a new world ethic, SCM Press, London.

Mashinini, M.M., 2015, 'The parables of Jesus as critique on food security systems for vulnerable households in urban townships', PhD thesis, Department of New Testament Studies, University of Pretoria.

Oakman, D.E., 2008, Jesus and the peasants. Cascade Books, Eugene, OR. (Matrix: The Bible in Mediterranean Context.)

Rohrbaugh, R.L., 1993, 'A peasant reading of the talents/pounds: A text of terror', Biblical Theology Bulletin 23, 32-39. http://dx.doi.org/10.1177/ 014610799302300105

Sachs, A., 1997, Soobramoney v Minister of Health, viewed 26 October 2015, from http://www.saflii.org/za/cases/ZACC/1997/17.html1997

Sachs, A., 2006, Dikoko v Mokhatla, viewed 26 October 2015, from http://www.saflii. org/za/cases/ZACC/2006/10.html2006

Sachs, A., 2009, The strange alchemy of life and law, Oxford University Press, Oxford.

Salazar, P-J. \& Doxtader, E., 2007, Truth and reconciliation in South Africa: The fundamental documents, Institute for Justice and Reconciliation, Cape Town.

Scott, B.B., 1989, Hear then the parable: A commentary on the parables of Jesus, Fortress Press, Minneapolis, MN

Terreblanche, S.J., 2002, A history of inequality in South Africa, 1652-2002, University of Kwazulu-Natal Press, Pietermaritzburg.

Truth and Reconciliation Commission, 1998, Truth and Reconciliation Commission of South Africa report, vol. 1, Truth and Reconciliation Commission.

Tutu, D., 2000, No future without forgiveness, Rider, Johannesburg.

Van Eck, E., 2009a, 'Interpreting the parables of the Galilean Jesus: A social-scientific approach', HTS Teologiese Studies/Theological Studies 65(1), Art. \#308, 12 pages.

Van Eck, E., 2009b, 'When patrons are not patrons: A social-scientific reading of the rich man and Lazarus (Lk 16:19-26)', HTS Teologiese Studies/Theological Studies 65(1), Art. \#309, 11 pages. http://dx.doi.org/10.4102/hts.v65i1.309

Van Eck, E., 2011a, 'Do not question my honour: A social-scientific reading of the parable of the Minas (Lk 19:12b-24, 27)', HTS Teologiese Studies/Theological Studies 67(3), Art. \#977, 11 pages. http://dx.doi.org/10.4102/hts.v67i3.977

Van Eck, E., 2011b, 'When neighbours are not neighbours: A social-scientific reading of the parable of the Friend at Midnight (Lk 11:5-8)', HTS Teologiese Studies/ Theological Studies 67(1), Art. \#788, 14 pages. http://dx.doi.org/10.4102/hts. v67i1.788

Van Eck, E., 2013, 'When patrons are patrons: A social-scientific and realistic reading of the parable of the Feast (Lk 14:16b-23)', HTS Teologiese Studies/ Theological Studies 69(1), Art. \#1375, 14 pages. http://dx.doi.org/10.4102/hts.v69i1.1375

Van Eck, E., 2014, 'The harvest and the kingdom: An interpretation of the Sower (Mk 4:3b-8) as a parable of Jesus the Galilean', HTS Teologiese Studies/Theological Studies 70(1), Art. \#2715, 10 pages. http://dx.doi.org/10.4102/hts.v70i1.2715

Van Eck, E., 2015a, 'Honour and debt release in the parable of the Unmerciful Servant (Mt 18:23-33): A social-scientific and realistic reading', HTS Teologiese Studies/ Theological Studies 71(1), Art. \#2838, 11 pages. http://dx.doi.org/10.4102/hts. v71i1.2838

Van Eck, E., 2015b, 'When an outsider becomes an insider: A social-scientific and realistic reading of the Merchant (Mt 13:45-46)', HTS Teologiese Studies/ Theological Studies 71(3), Art. \#2859, 8 pages. http://dx.doi.org/10.4102/hts. v71i3.2859 